\title{
So that we remember
}

\author{
Stephen Hancocks OBE \\ Editor-in-Chief
}

The BDJ Upfront section includes editorials, letters, news, book reviews and interviews. Please direct your correspondence to the News Editor,

Adrian O’Dowd at BDJNews@nature.com. Press releases or articles may be edited, and should include a colour photograph if possible.

$\mathrm{T}$ his issue presents an unusual confluence of two mighty and significant themes, mouth cancer and a remembrance of the ending of the First World War. Professor Mike Lewis, to whom we are very grateful for his work in assembling such an enviable set of papers as Guest Editor of this mouth cancer themed issue, focusses on this subject in his Editorial. Being able to publish this in Mouth Cancer Action Month marks important support for this worthy annual campaign.

Consequently this enables me to reflect on the other very timely matter, the $B D$ J's participation in marking the centenary of the beginning of World War One (WWI) and now, the Armistice. The cover of this issue is unique in that it breaks the recent pattern of twelve covers, each issue of a given volume, following a theme. We have broken this convention by commissioning a further illustration from the artist, Philip Bannister, who painted our series in 2014 recording the involvement of dentistry in the Great War. Planning for cover series starts anything up to two years before they appear and identifying dentistry in WWI as a theme dates back to meetings in 2012/13. Our Art Editor, Melissa Cassem, set off to discover what material was available on the subject, a journey which also ultimately found various members of the editorial team visiting museums, libraries and archives. What became apparent was that in 1914 there was no dental component of the UK armed forces and it was an incident in which General Haig suffered toothache at the battle of Aisne to be attended by a French dental surgeon from Paris that caused the trail to begin. The rest, as the well-worn phrase informs us, is history, as the gradual deployment and later development of dentistry took place in the army and other branches of the armed services.

Melissa's research provided us with a further problem. Such material as did exist was disparate, fragmented and consisted of several different media ranging from early radiographs, photographs and paintings to study models of maxillofacial injuries and instruments of the time. How to unify these into a series? We decided to commission an artist to create watercolours of the various materials and chose Philip who by a positive coincidence had a grandfather who fought in the WWI, thereby providing him with an opportunity to simultaneously honour the memory of his family member.

The resulting 12 paintings are a credit to all involved and the added motif from Philp of the poppy on each of them provided a
Rachel Bairsto, who had also been central to the research behind the series. ${ }^{1}$

The cover on this issue, appropriately and poignantly, features the list of names of BDA members who died in WWI.

They are commemorated in a memorial at the BDA headquarters in front of which members and staff mark the annual silence on 11 November and in addition to which this cover will now form a part. To complete the circle, as it were, we are also pleased to be able to publish in this issue a paper by Fiona Gray who has diligently researched the background to the BDA Memorial and the biographic details of those so listed, which

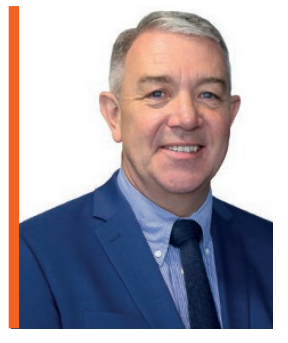

\section{'I hope that readers will take a moment to reflect and count blessings, both so that we remember and lest we forget.'}

striking and much commented upon series. As is standard procedure the Journal paid for the right to reproduce the artwork while the originals remained in the ownership of the artist. However, the same barriers that we had faced in assembling the subject history had also been experienced by the Royal Army Dental Corps, meaning that the Dental Archive of the Army Medical Services Museum was also short of WWI material. As a consequence, and thanks to generous donations made by past members of the Corps, sufficient funds were raised to allow the purchase and framing of the original watercolours which now form part of a permanent exhibition on display in that museum. In an extension of this generosity, a set of signed, limited edition prints made from the originals was also presented to the BDA's Museum and received by the curator complements her pervious paper on the first dentists sent to the Western Front. ${ }^{2,3}$

We are grateful to all who have contributed to this unique, informative and fascinating story and my hope is that by these means the $B D J$ has added a small but important element to the respect that the centenary of the Armistice has generated for the fallen, the injured, the damaged and those who survived.

I hope too that readers will take a moment to reflect, give thanks and count blessings, both so that we remember and lest we forget.

DOI: 10.1038/sj.bdj.2018.979

1. BDJ World War I cover series. Br Dent J 2015; 219: 150.

2. Gray F S S. The BDA First World War Memorial. Br Dent J 2018; 225: 892-897.

3. Gray F S S. The first dentists sent to the Western Front during the First World War. Br Dent J 2017; 222: 893-897. 